\section{OPTIMALISASI KINERJA PEGAWAI}

Untuk membangun usaha yang besar dan baik, maka diperlukan suatu proses manajemen sumber daya manusia berupa optimalisasi kinerja pegawai. Suatu perusahaan atau bisnis akan berjalan sempurna jika kinerja pegawai bisa ditingkatkan. Oleh karena itu, optimalisasi kinerja pegawai menjadi suatu hal yang perlu dilakukan oleh setiap pelaku usaha. Proses optimalisasi kinerja pengawai merupakan suatu hal yang kompleks, hal ini karena kinerja pegawai dipengaruhi oleh banyak faktor dan kondisi. Untuk melakukan optimalisasi, perlu adanya kajian yang mengungkap faktor kunci sehingga bisa melakukan optimalisasi kinerja karyawan secara baik.

Buku ini dirancang oleh dosen dan praktisi usaha yang mahir sehingga bisa menjabarkan bagaimana dan apa saja yang perlu diperhatikan dalam melakukan optimalisasi kinerja pegawai. Bagi anda yang ingin mengembangkan bisnis ke skala yang lebih besar dan luas, maka buku ini sangat tepat bagianda.

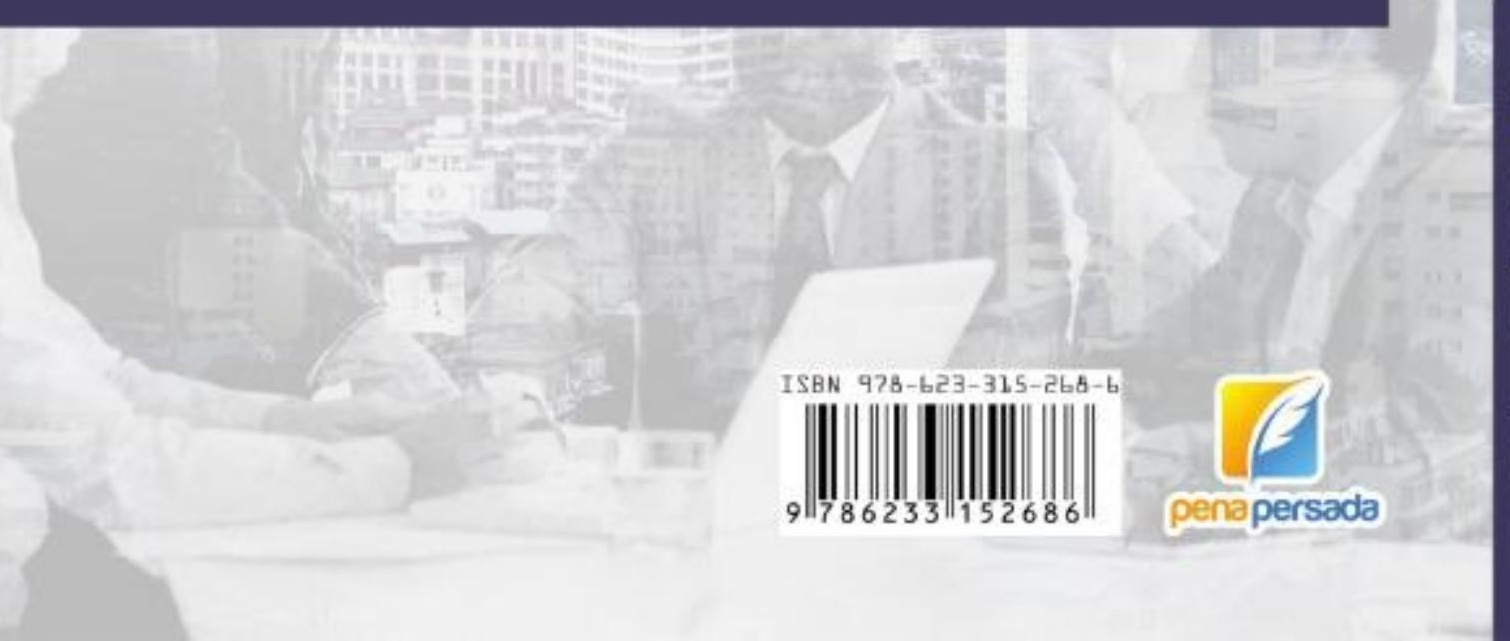

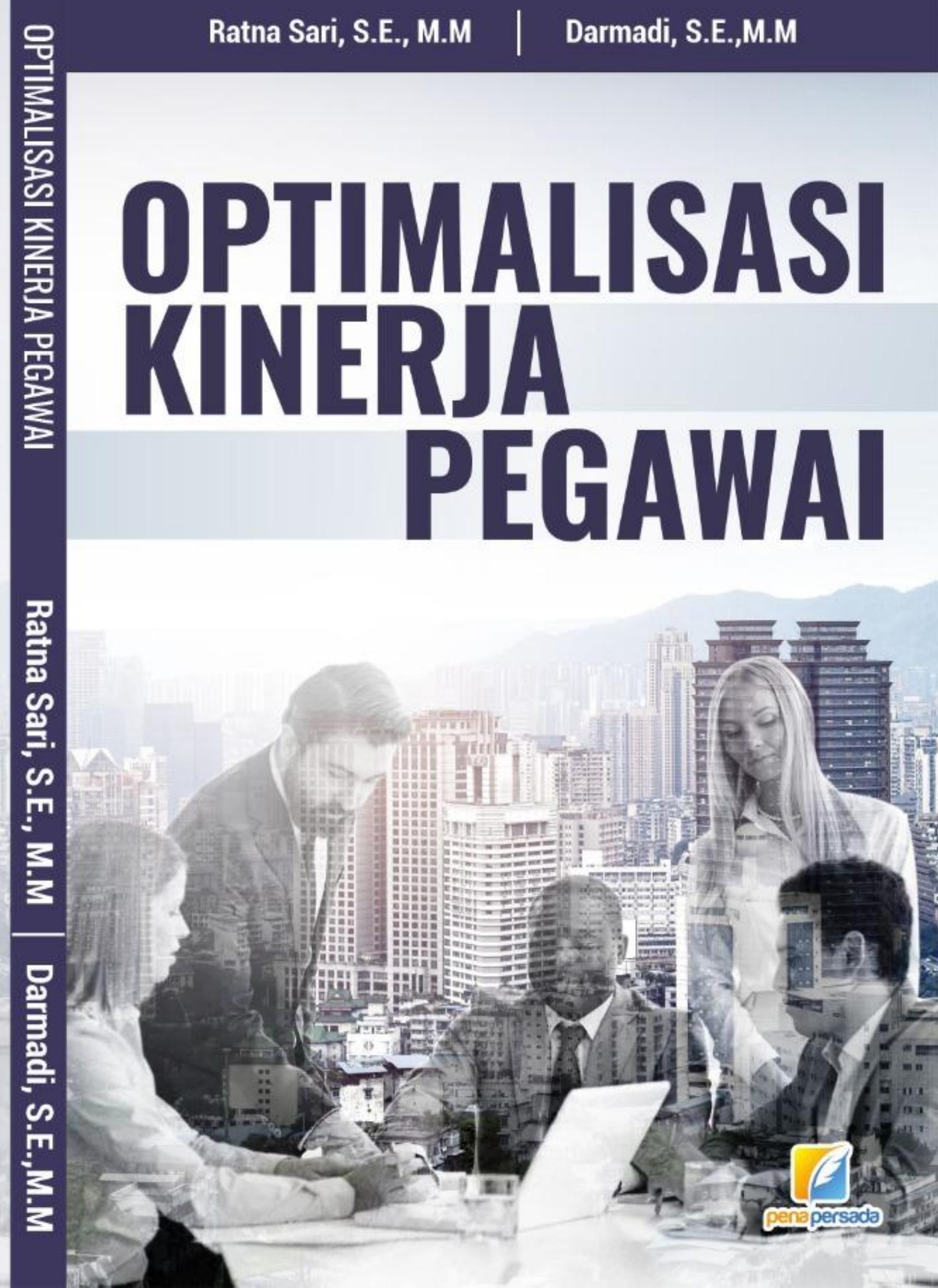




\title{
OPTIMALISASI KINERJA PEGAWAI
}

\author{
Ratna Sari, S.E., M.M \\ Darmadi, S.E.,M.M
}

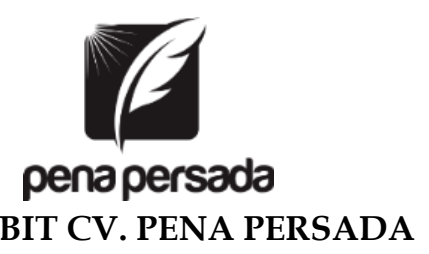




\title{
OPTIMALISASI KINERJA PEGAWAI
}

\author{
Penulis: \\ Ratna Sari, S.E., M.M \\ Darmadi, S.E.,M.M
}

ISBN : 978-623-315-268-6

\section{Editor:}

Wiwit Kurniawan

Design Cover :

Retnani Nur Briliant

Layout :

Hasnah Aulia

\section{Penerbit CV. Pena Persada \\ Redaksi :}

Jl. Gerilya No. 292 Purwokerto Selatan, Kab. Banyumas

Jawa Tengah

Email : penerbit.penapersada@gmail.com

Website : penapersada.com Phone : (0281) 7771388

\section{Anggota IKAPI}

All right reserved

Cetakan pertama : 2021

Hak Cipta dilindungi oleh undang-undang. Dilarang memperbanyak karya tulis ini dalam bentuk apapun tanpa izin penerbit 


\section{KATA PENGANTAR}

Puji syukur saya panjatkan kepada Tuhan Yang Maha Esa, karena atas berkat dan rahmat-Nya, saya dapat menyelesaikan buku ini. Penulisan buku merupakan buah karya dari pemikiran penulis yang diberi judul "Optimalisasi Kinerja Pegawai." Saya menyadari bahwa tanpa bantuan dan bimbingan dari berbagai pihak sangatlah sulit bagi saya untuk menyelesaikan karya ini. Oleh karena itu, saya mengucapkan banyak terima kasih pada semua pihak yang telah membantu penyusunan buku ini. Sehingga buku ini bisa hadir di hadapan pembaca.

Penulis menyadari bahwa buku ini masih jauh dari kesempurnaan. Oleh karena itu kritik dan saran yang membangun sangat dibutuhkan guna penyempurnaan buku ini. Akhir kata saya berharap Tuhan Yang Maha Esa berkenan membalas segala kebaikan semua pihak yang telah membantu. Semoga buku ini akan membawa manfaat bagi pengembangan ilmu pengetahuan. 


\section{DAFTAR ISI}

DAFTAR ISI iv

$\begin{array}{ll}\text { BAB I } & 1\end{array}$

PERMASALAHAN KINERJA PEGAWAI 1

A. Perilaku Kontra Produktif..................................................1

B. Mengelola dan Meningkatkan Kinerja .............................4

1. Diskusikan masalah tersebut dengan karyawan secara langsung ........................................................... 4

2. Mendokumentasikan diskusi dan hasil yang diharapkan ............................................................. 6

3. Buat rencana peningkatan kinerja, atau hentikan karyawan tersebut......................................................

C. Apa yang Dimaksud dengan Prestasi Kerja yang

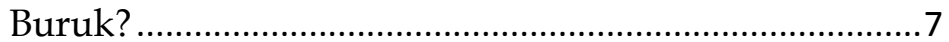

D. Penyebab Potensial dari Pekerjaan yang Buruk ..........10

E. Manajemen untuk Mengatasi Kinerja Buruk ................12

F. Apa yang Dimaksud dengan Kinerja Buruk? ..............14

1. Apa kinerja yang dapat diterima? .............................15

2. Apa yang membuat kerja menjadi bagus? ..............17

3. Kinerja Rendah dan Keuntungan perusahaan........19

4. Kinerja Rendah Mempengaruhi Moral dan Keuntungan Perusahaan ...........................................20

5. Haruskah mereka tinggal atau pergi? ......................21 
G. Menghindari Perekrutan Karyawan dengan Kinerja

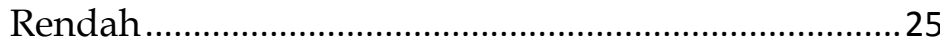

1. Bersikap spesifik dengan fakta yang ada ...............27

2. Pertimbangkan kebutuhan karyawan Anda...........28

3. Fokus pada umpan balik...........................................28

4. Memberikan Teknologi Pendukung Kinerja...........29

5. Tawarkan penghargaan dan pengakuan.................29

BAB II 31

MANAJEMEN SUMBER 31

DAYA MANUSIA

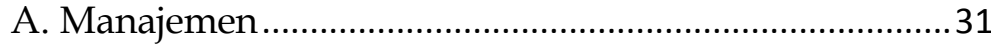

1. Pengertian Manajemen.................................................31

2. Fungsi Manajemen.......................................................... 32

3. Tingkatan Manajemen .................................................33

4. Unsur Manajemen........................................................... 34

B. Manajemen Sumber Daya Manusia.................................36

1. Pengertian Sumber Daya Manusia ............................36

2. Pengertian Manajemen Sumber Daya Manusia .....37

3. Tujuan Manajemen Sumber Daya Manusia .............39

4. Fungsi Manajemen Sumber Daya Manusia .............39

5. Peranan Manajemen Sumber Daya Manusia ...........41

BAB III 43

KONSEP KINERJA

A. Syarat Penilaian Kinerja ................................................46

B. Metode Penilaian Kinerja ..............................................47

C. Konsep dan Definisi Kinerja ..........................................49 
D. Model Kinerja Pekerjaan: Dimensi yang Berlaku di Seluruh Pekerjaan..........................................................56

BAB IV

FAKTOR YANG MENDORONG OPTIMALISASI KINERJA KARYAWAN

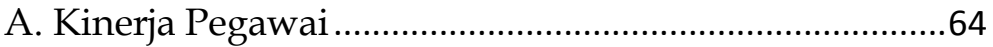

1. Pengertian Kinerja Pegawai.......................................64

2. Faktor-faktor yang Mempengaruhi Kinerja ............68

3. Tujuan dan Kegunaan Penilaian Kinerja ..................69

4. Manfaat dan Tujuan Kinerja .......................................70

5. Dimensi dan Indikator Kinerja Pegawai...................71

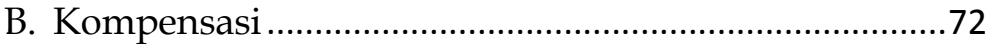

1. Pengertian Kompensasi...............................................72

2. Jenis- Jenis Kompensasi...............................................73

3. Tujuan Pemberian Kompensasi ..................................73

4. Asas Kompensasi ...........................................................75

5. Sistem Kompensasi ......................................................75

6. Faktor-Faktor Yang Mempengaruhi Kompensasi ..76

7. Metode Kompensasi ......................................................77

8. Dimensi dan Indikator Kompensasi..........................77

C. Budaya Organisasi ...........................................................79

1. Pengertian Budaya Organisasi ....................................79

2. Karakteristik Budaya Organisasi ................................80

3. Fungsi Budaya Organisasi ........................................... 81

4. Tingkatan Budaya Organisasi .....................................82

5. Pembentukan Budaya Organisasi...............................83 
6. Proses Budaya Organisasi...........................................83

7. Dimensi dan Indikator Budaya Organisasi ..............84

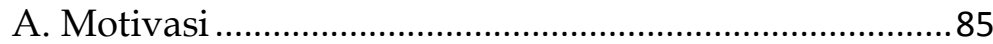

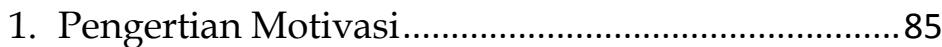

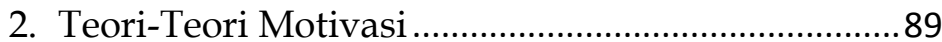

3. Tujuan dan Manfaat Motivasi ..................................101

4. Jenis-Jenis Motivasi..................................................101

5. Konsep Model Motivasi Kerja ..................................102

6. Metode Motivasi Kerja .............................................102

7. Teori Maslow …..........................................................103

8. Dimensi dan Indikator Motivasi ..............................105 


\section{BAB I \\ PERMASALAHAN KINERJA PEGAWAI}

\section{A. Perilaku Kontra Produktif}

Salah satu permasalahan kinerja pegawai adalah perilaku kontraproduktif yang dilakukan oleh mereka. Perilaku ini menghambat kinerja dan produktivitas yang berdampak pada keberhasilan perusahaan. Salah satu pendekatan untuk menganalisa perilaku kontraproduktif menantang untuk diintegrasikan dengan model kinerja kerja Campbell (1990) dan Motowidlo et al. (1997).

Terlepas dari label yang dipilih untuk perilaku kontraproduktif yang mengurangi efektivitas organisasi, apa sifat dasar mereka? Apakah kurangnya pengetahuan dan keterampilan mendasari perilaku kontraproduktif yang tidak terlalu merusak?

Kurangnya pengetahuan dan keterampilan ini dapat terwujud dalam perilaku yang sangat merusak secara tidak tepat (misalnya, kekerasan di tempat kerja, pencurian besar-besaran) atau, dalam istilah pengetahuan, kurangnya kesadaran bahwa perilaku kontraproduktif yang memiliki konsekuensi organisasi yang serius. Atau apakah orang yang melakukan perilaku berbahaya minimal memiliki jenis pengetahuan dan 
keterampilan khusus yang memfasilitasi tindakan kontraproduktif dengan intensitas rendah (misalnya, menyadari bahwa rekan kerja tidak akan memperhatikan jika beberapa pena hilang dari lemari sumber daya) tetapi menghalangi mereka untuk melakukan tindakan kontraproduktif berintensitas tinggi (misalnya, menyadari bahwa pencurian sumber daya perusahaan dalam skala besar terlalu berbahaya dan sulit untuk dilakukan)?

Jenis pengetahuan dan keterampilan yang mendasari perilaku kontraproduktif dengan konsekuensi serius bagi efektivitas organisasi kurang dipelajari dalam psikologi I-O karena sifatnya yang tidak diinginkan secara sosial. Contoh dari jenis pengetahuan ini mungkin mencakup cara menyabotase atau mencuri sumber daya perusahaan secara halus, cara menyembunyikan penyalahgunaan narkoba atau alkohol jangka panjang saat bekerja, dan cara mendapatkan dan menggunakan informasi rahasia tentang rekan kerja atau supervisor untuk keuntungan politik.

Contoh keterampilan yang dapat memfasilitasi perilaku kerja kontraproduktif intensitas tinggi mencakup kemampuan untuk memanipulasi orang lain, ketidakpekaan terhadap tekanan emosional atau fisik orang lain, dan kemahiran dalam melakukan tindakan kekerasan terhadap manusia lain.

Ini adalah persoalan yang menantang. Jawaban atas hal ini dapat memiliki implikasi penting untuk pemilihan dan pelatihan karyawan dalam perusahaan/organisasi. Mengidentifikasi pengetahuan dan anteseden berbasis 
keterampilan dari perilaku kontraproduktif dapat mengarah pada pengembangan penilaian yang dapat mengukur atribut ini secara andal dalam proses melamar kerja, ini dapat memastikan bahwa mereka yang memilki sifat-sifat tersebut tidak akan diterima kerja.

Selain mengidentifikasi pengetahuan dan keterampilan anteseden dari perilaku kontraproduktif, mengembangkan pemahaman menyeluruh tentang bagaimana anteseden ini berhubungan secara psikologis dengan perilaku kerja yang menyimpang dapat membantu dalam membangun sistem untuk mencegah seseorang yang sudah memiliki sifat kontraproduktif untuk mengekspresikan perilaku mereka yang dapat merugikan organisasi dan perusahaan.

Karyawan yang berkinerja buruk dapat menghabiskan waktu dan uang yang berharga dari perusahaan. Jadi sangat penting untuk mengatasi situasi ini secepat mungkin. Banyak sebab yang membuat karyawan memiliki kinerja yang buruk. Namun, hal baiknya adalah banyak di antaranya dapat diselesaikan dengan rencana yang tepat.

Jika Anda ingin meningkatkan organisasi, penting untuk mempelajari cara mengidentifikasi, mengkomunikasikan, dan meningkatkan kinerja karyawan yang buruk. 


\section{B. Mengelola dan Meningkatkan Kinerja}

Membahas kinerja karyawan yang buruk bisa jadi tidak nyaman, tetapi ini harus dilakukan sesegera mungkin saat melihat ada masalah. Menunda diskusi ini hanya akan terus merugikan bisnis. Sebagian besar kinerja karyawan dapat meningkat dengan proses yang tepat, jadi setiap bisnis kecil harus menguraikan rencana formal untuk mengelola dan meningkatkan kinerja yang kurang baik.

"Bisnis kecil jatuh ke dalam perangkap pemikiran bahwa mereka tidak memerlukan hal yang sama yang mereka temukan dalam bisnis besar seperti kebijakan formal, program manajemen kinerja, atau bahkan proses disiplin yang terdokumentasi.

Chris Young, direktur pengembangan tenaga kerja di Departemen Transportasi Texas, menyampaikan bahwa "Faktanya, bisnis kecil memiliki lebih sedikit ruang untuk risiko hukum dan membutuhkan hal-hal ini bahkan lebih dari perusahaan besar. Memiliki kebijakan dan proses formal untuk kinerja dan disiplin juga akan memprofesionalkan tenaga kerja Anda lebih cepat daripada hanya mengembangkannya."

Berikut adalah proses tiga langkah yang dapat diikuti bisnis kecil untuk mengelola dan meningkatkan kinerja karyawan.

1. Diskusikan masalah tersebut dengan karyawan secara langsung

Langkah pertama dalam meningkatkan kinerja adalah manajer karyawan tersebut melakukan percakapan pribadi dengan mereka tentang masalah tersebut. Dekati percakapan dengan rasa ingin tahu, 
bukan tuduhan. Jika perlu, libatkan orang HR yang dapat membantu memimpin diskusi.

Tujuannya bukan hanya untuk mengungkap masalah, tetapi juga menetapkan solusi yang memberi kesempatan kepada karyawan untuk sukses. Bersikaplah langsung dan jelas tentang apa yang ingin Anda capai, angkat masalah dengan karyawan secara profesional, non-pribadi.

Cory Colton, pelatih eksekutif utama di Inflection Point Coaching, memberikan contoh:

Katakanlah, "Saya perhatikan bahwa tugas X belum selesai sesuai dengan waktu yang kita setujui."

Jangan katakan, "Saya perhatikan Anda tidak menyelesaikan tugas tepat waktu."

Tindaklanjuti pernyataan tersebut dengan rasa ingin tahu. Misalnya, bisa bertanya, "Bisakah Anda membantu saya memahami apa yang terjadi yang menyebabkan tenggat terlewati?"

Pemimpin dan manajer harus terbuka terhadap umpan balik dari karyawan. Di akhir diskusi, kedua pihak harus menyepakati apa yang diperlukan agar karyawan tersebut berhasil dan membuat rencana tentang bagaimana mereka akan bergerak maju dan memeriksa kemajuan.

Young mengutip pendekatan verbal serupa yang dapat Anda lakukan untuk menyapa karyawan metode FOSA (Fakta, Tujuan, Solusi, Tindakan). Dalam model peningkatan kinerja ini, manajer mengidentifikasi fakta-fakta kinerja yang buruk. 
Kemudian kita menghubungkan kinerja yang diinginkan dengan tujuan organisasi dan menunggu karyawan menawarkan lebih dari dua solusi. Sangat penting bagi karyawan untuk mengembangkan solusi, karena siapa pun yang muncul dengan ide yang dimilikinya, dan manajer ingin karyawan mereka memiliki solusi mereka sendiri. Akhirnya, mereka semua menyetujui tindakan tertentu dan tanggal untuk meninjau kembali rencana tersebut.

2. Mendokumentasikan diskusi dan hasil yang diharapkan

Selain membahas masalah dan solusi tentang kinerja karyawan, perlu juga mendokumentasikan proses tersebut secara formal. Perlu menyimpanan dokumen internal untuk referensi dan memberikan surat pemberitahuan kepada karyawan tentang kinerja yang tidak memuaskan.

Sertakan detail tentang kinerja karyawan, masalah (misalnya, kualitas, waktu, perilaku), langkah-langkah yang telah diambil, dan langkahlangkah yang disepakati yang akan diambil untuk ke depannya.

Mendokumentasikan informasi ini dapat membantu mengevaluasi kesuksesan karyawan di masa depan. Jika kinerja tidak membaik dan perlu memilih opsi untuk memberhentikan karyawan tersebut, dokumentasi dapat berfungsi sebagai perlindungan dan bukti mengapa manajemen membuat keputusan tersebut. 
3. Buat rencana peningkatan kinerja, atau hentikan karyawan tersebut.

Jika karyawan tidak mulai memenuhi harapan baru yang telah disepakati, inilah saatnya untuk meninjau kembali percakapan dengan cara yang lebih serius. Adakan diskusi tatap muka lainnya dengan karyawan tersebut tentang apakah mereka akan paling berhasil tetap dalam peran mereka saat ini, pindah ke peran lain dalam perusahaan atau meninggalkan perusahaan sama sekali.

Jika karyawan memutuskan bahwa mereka ingin tetap dalam peran mereka saat ini, maka rencana peningkatan kinerja dapat dibuat tidak hanya menguraikan cara yang jelas menuju kesuksesan, tetapi juga mencakup kemauan untuk berkomitmen atas tugas apapun (pendampingan, pembinaan, pelatihan, diskusi SDM) dan siap untuk konsekuensi akhir jika kinerja tidak membaik.

Poin utama dari uraian di atas adalah untuk meningkatkan kinerja karyawan yang buruk, diperlukan proses diskusi dua arah dengan karyawan, membuat rencana perbaikan karyawan, dan mendokumentasikan kejadian tersebut.

\section{Apa yang Dimaksud dengan Prestasi Kerja yang Buruk?}

Untuk mengelola dan meningkatkan kinerja karyawan, Anda memerlukan pemahaman yang jelas tentang apa itu kinerja yang buruk. Seorang karyawan menunjukkan kinerja kerja yang buruk ketika tindakan, keluaran dan / atau perilaku mereka tidak memenuhi tanggung jawab pekerjaan atau ekspektasi organisasi mereka yang didefinisikan dengan jelas . 
Seberapa baik kinerja seorang karyawan didasarkan pada kombinasi beberapa faktor: kemampuan, kemauan, dan kapasitas mereka untuk menyelesaikan tugasnya; kemampuan manajemen untuk menetapkan dan mengkomunikasikan tujuan karyawan SMART ; kemampuan perusahaan untuk mengkomunikasikan misi, visi dan nilai-nilainya; dan budaya perusahaan yang mendorong keselamatan, inklusi, dan transparansi. Jika salah satu - atau semua - dari faktor-faktor ini kurang, karyawan cenderung menunjukkan kinerja kerja yang buruk.

Perilaku spesifik yang membentuk "kinerja buruk" dapat bervariasi menurut konteks bisnis dan departemennya. Misalnya, Anthony Babbitt, konsultan manajemen perubahan dan ahli strategi bisnis di Babbitt Consulting, mengatakan perusahaan manufaktur dapat mengukur kinerja berdasarkan produktivitas, seperti unit yang dapat diterima per jam, sedangkan departemen SDM dapat mengidentifikasi kinerja yang buruk dengan tingkat pergantian karyawan yang tinggi .

Dalam pekerjaan pelayanan, kinerja mungkin sama pentingnya dengan kualitas pekerjaan dan juga tentang kemampuan seseorang untuk berinteraksi dengan pelanggan. Setiap perusahaan mendefinisikan konsep ini secara berbeda, tetapi hal ini adalah salah satu perbedaan penting dari perusahaan. Karena definisi ini biasanya menjadi faktor penentu apakah seorang karyawan akan dipertahankan atau diberhentikan. 
Kinerja kerja yang buruk adalah ketika hasil atau perilaku karyawan tidak memenuhi harapan pemberi kerja, yang mungkin berbeda menurut industri, perusahaan, atau peran pekerjaan.

Bagaimana mengidentifikasi kinerja kerja yang buruk? Untuk mengidentifikasi dengan baik bagaimana kinerja karyawan, tetapkan ekspektasi dan sasaran yang jelas segera setelah karyawan dipekerjakan. Kemudian mengukur kinerja mereka terhadap metrik tersebut. Manajer dan supervisor harus selalu berkomunikasi dengan bawahannya untuk memberikan umpan balik dan mendiskusikan masalah apa pun yang muncul.

Seorang pemimpin yang baik dan karyawan yang unggul tidak akan pernah memunculkan masalah kinerja yang serius. Hal ini karena adanya diskusi yang rutin tentang tugas, harapan, dan hasil, dan mekanisme untuk mengidentifikasi risiko, hambatan, dan kesenjangan dari pimpinan dan karyawannya.

Melakukan survei karyawan adalah cara lain untuk membandingkan kinerja karyawan dengan harapan yang telah digariskan. Paling tidak, setiap organisasi harus melakukan survei tinjauan tahunan, yang memberi pengusaha dan karyawan kesempatan untuk mengevaluasi kinerja secara formal dan mengidentifikasi titik-titik rasa sakit. Organisasi dapat memberikan survei tambahan, seperti survei untuk keterlibatan dan kepuasan karyawan, untuk memahami apakah staf mereka merasa didukung dan dipenuhi dalam peran mereka. Jenis survei ini dapat meningkatkan moral perusahaan dan meningkatkan retensi karyawan. 
Tetapkan ekspektasi yang jelas untuk karyawan segera setelah mempekerjakan karyawan, dan seringseringlah mengukur kinerja setiap karyawan berdasarkan metrik tersebut.

\section{Penyebab Potensial dari Pekerjaan yang Buruk}

Meskipun ada banyak kemungkinan penyebab internal dan eksternal bagi seorang karyawan untuk berkinerja buruk di tempat kerja, Colton mengatakan kinerja yang buruk paling sering disebabkan oleh kurangnya kesepakatan antara karyawan dan pemimpin mereka tentang pekerjaan itu sendiri, kualitas, harapan dan atau deadline untuk penyelesaian. Inilah mengapa perlu menetapkan ekspektasi yang jelas dan menjaga jalur komunikasi terbuka.

Kinerja yang buruk juga dapat disebabkan oleh karyawan yang tidak memiliki pengetahuan atau keterampilan untuk menyelesaikan tugas atau proyek tertentu, dalam hal ini adalah peran pemimpin untuk membimbing, membimbing atau membimbing mereka untuk pertumbuhan profesional mereka.

Jika ada keamanan psikologis, maka karyawan akan dengan sukarela meningkatkan kesenjangan pengetahuan dengan pemimpin mereka, yang dapat mendukung mereka atau menugaskan kembali pekerjaan di seluruh tim untuk mencapai tujuan. 
Kinerja yang buruk dapat berasal dari kurangnya kemauan atau kemampuan (misalnya, seorang karyawan yang kelelahan atau tidak bahagia dengan pekerjaannya kemungkinan besar berkinerja buruk), dan beberapa pekerjaan tidak sesuai untuk karyawan tertentu.

Pertimbangkan Prinsip Peter ketika mempromosikan karyawan. Yakni gagasan bahwa karyawan yang berkinerja baik terus dipromosikan sampai mereka tidak dapat lagi bekerja dengan baik. Babbitt memberikan contoh perusahaan yang mempromosikan pemrogram perangkat lunak dengan kepribadian introvert ke posisi manajemen yang mengharuskan mereka berinteraksi dengan baik dengan orang lain. Walaupun mereka adalah programmer yang hebat, pekerjaan baru ini mungkin tidak sesuai dengan sifat mereka.

Manajemen yang buruk, visi perusahaan yang kurang, lingkungan kerja yang beracun (mis., Intimidasi, pelecehan, diskriminasi) dan masalah pribadi juga dapat menyebabkan kinerja karyawan menurun.

Perubahan mendadak dan tak terduga dalam kesehatan dan kesejahteraan karyawan atau situasi keluarga mereka mungkin juga menjadi faktor luar yang menyebabkan kinerja yang buruk. Perubahan lingkungan yang tidak terduga, seperti pandemi COVID, dapat menyebabkan karyawan yang pernah berkinerja tinggi mengalami hambatan kinerja, atau membutuhkan dukungan untuk menavigasi kebutuhan pribadi dan rumah yang tidak terduga. 